\title{
Brugada electrocardiographic findings in an 80-year-old man
}

\author{
Antonio Mirijello, Giovanni Addolorato, Raffaele Landolfi
}

Department of Internal Medicine, Catholic University of Rome, Rome, Italy

\section{Correspondence to} Dr Antonio Mirijello, antonio.mirijello@gmail.com

\section{DESCRIPTION}

An 80-year-old man was admitted to our inpatient unit because of pneumonia. An ECG performed during fever $\left(39^{\circ} \mathrm{C}\right)$ showed a regular rhythm, normal PR interval, RSR' with ST-elevation in V1/V3 leads with normal QRS duration. In particular, V2 lead showed a coved-type ST-segment, consistent with type-1 Brugada alteration (figure 1). The patient's clinical and family history was unremarkable for symptomatic arrhythmias, syncope or sudden death. An ECG performed with normal body temperature $\left(36.5^{\circ} \mathrm{C}\right)$ showed ST-elevation in V1/V3 leads, with a saddleback-type ST-segment in V2, consistent with type-2 Brugada alteration (figure 2).

Brugada syndrome, first described in $1992,{ }^{1}$ is a clinical entity characterised by typical ECG alterations associated with a high risk of sudden cardiac death. These ECG patterns can be seen spontaneously, induced by sodium channel blocking agents or by hyperthermia. One of the proposed pathological mechanisms is an alteration in the sodium

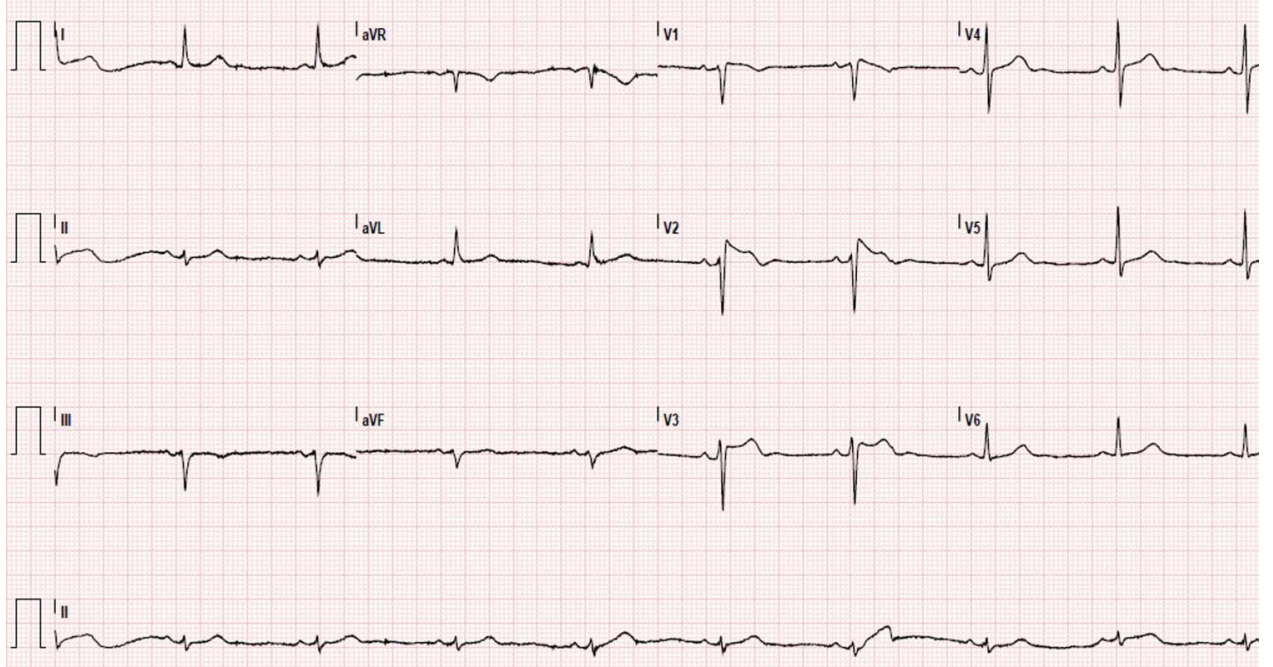

Figure 1 Type 1 Brugada ECG: coved-type ST-segment in V2.

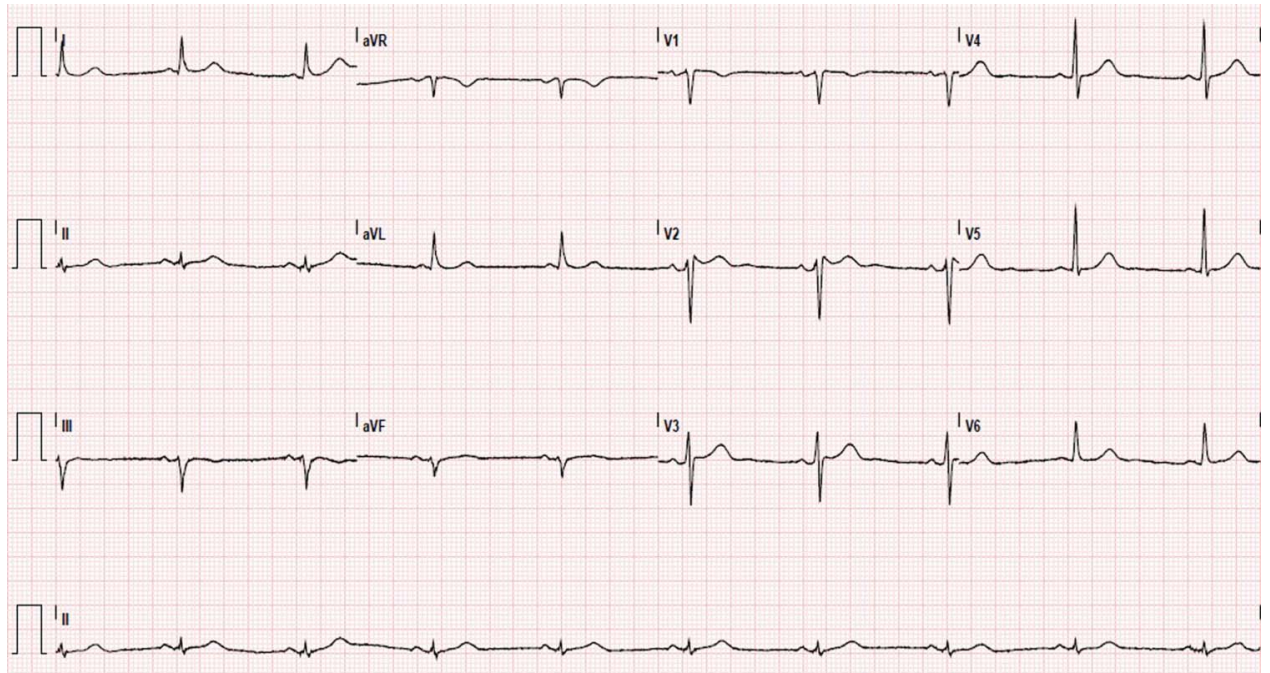




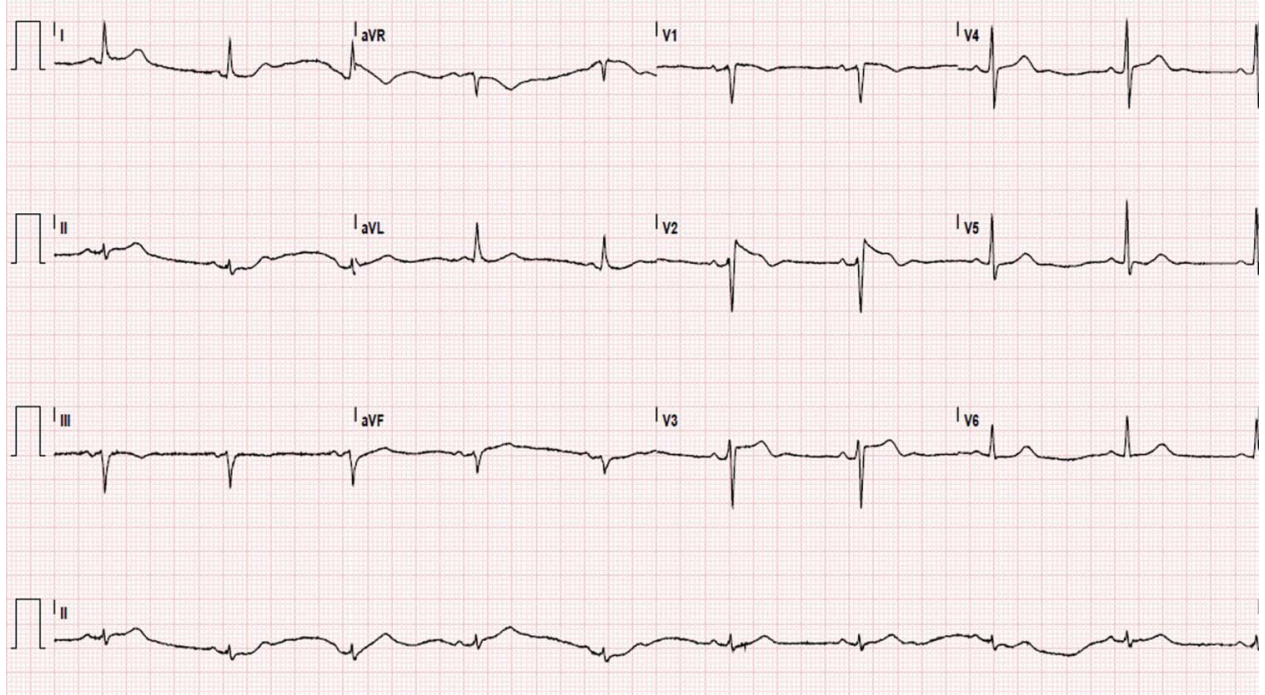

Figure 3 ECG recorded in concomitance with a second febrile episode showing type-1 Brugada pattern.

channels, with temperature-induced accelerated inactivation or impaired conductance. ${ }^{2}$ It has been reported that fever can induce a Brugada-type ECG pattern in asymptomatic patients disclosing Brugada syndrome, even outperforming flecainide test. ${ }^{3}$ In this connection, in our patient the flecainide challenge test was not performed since the patient did not give his consent. However, concomitant with another episode of fever, a new ECG was recorded (figure 3), showing the reappearance of type-1 Brugada alterations.

Since febrile illness, unmasking Brugada electrical disturbances, could precipitate ventricular arrhythmias, it is important to aggressively reduce body temperature in order to minimise the risk of sudden cardiac death.
Contributors AM, GA and RL designed, wrote and reviewed the manuscript. AM also managed the patient during the hospitalisation.

Competing interests None.

Patient consent Obtained.

Provenance and peer review Not commissioned; externally peer reviewed.

\section{REFERENCES}

1 Brugada P, Brugada J. Right bundle branch block, persistent ST segment elevation and sudden cardiac death: a distinct clinical and electrocardiographic syndrome. A multicenter report. J Am Coll Cardiol 1992;20:1391-6.

2 Dumaine R, Towbin JA, Brugada P, et al. Ionic mechanisms responsible for the electrocardiographic phenotype of the Brugada syndrome are temperature dependent. Circ Res 1999;85:803-9.

3 Barra S, Providência R, Nascimento J. Fever outperforms flecainide test in the unmasking of type 1 Brugada syndrome electrocardiogram. Europace 2013;15:394.

Copyright 2013 BMJ Publishing Group. All rights reserved. For permission to reuse any of this content visit

http://group.bmj.com/group/rights-licensing/permissions.

BMJ Case Report Fellows may re-use this article for personal use and teaching without any further permission.

Become a Fellow of BMJ Case Reports today and you can:

- Submit as many cases as you like

- Enjoy fast sympathetic peer review and rapid publication of accepted articles

- Access all the published articles

- Re-use any of the published material for personal use and teaching without further permission

For information on Institutional Fellowships contact consortiasales@bmjgroup.com

Visit casereports.bmj.com for more articles like this and to become a Fellow 